\title{
Host status of soybean genotypes to Meloidogyne arenaria and Meloidogyne morocciensis
}

\author{
Hospedabilidade de genótipos de soja a Meloidogyne arenaria e Meloidogyne morocciensis
}

\section{Daiane Dalla Nora ${ }^{1}$, Ricardo Rubin Balardin", Tiago Edu Kaspary², Ismail Teodoro de Souza Júnior³, Cristiano Bellé ${ }^{1^{*}}$}

${ }^{1}$ Phytus Group, Estação Experimental de Itaara, Itaara, RS, Brasil. * Author for correspondence: crbelle@gmail.com

${ }^{2}$ Instituto Nacional de Investigación Agropecuaria, Colonia, Uruguay.

${ }^{3}$ Universidade Federal do Rio Grande do Sul, Porto Alegre, RS, Brasil.

Submission: 19/03/2020 / Acceptance: 01/07/2020

\begin{abstract}
Soybean crop productivity is limited by several biotic factors, particularly plant-parasitic nematodes. Several species have been reported to cause crop damage, especially those of the genus Meloidogyne. Therefore, the aim of this study was to evaluate, the reaction of 28 soybean genotypes to Meloidogyne arenaria and $M$. morocciensis in a greenhouse. The soybean genotypes were the same for experiments with different species of plant-parasitic nematodes and were individually inoculated with 5,000 eggs + second-stage juveniles (J2) of Meloidogyne and kept in a greenhouse. After 60 days of inoculation, the roots of each plant were assessed for the number of galls, final population, and reproduction factor (RF = final population/initial population). The averages of the different variables were then compared to each other by the Scott-Knott cluster analysis at a significance level of $5 \%$. All of the soybean genotypes in the study were susceptible to both nematodes, with RF ranging from 3.5 to 24.1 for $M$. arenaria and 5.3 to 37.5 for M. morocciensis.
\end{abstract}

KEYWORDS: Glycine max, root-knot nematode, reproduction, susceptibility.

\section{RESUMO}

A cultura da soja tem sua produtividade limitada por diversos fatores bióticos, dentre estes destacam-se os fitonematoides. Várias espécies já foram relatadas causando danos à cultura, especialmente as do gênero Meloidogyne. Diante disso, o objetivo do trabalho foi avaliar, em casa de vegetação, a reação de 28 cultivares de soja a $M$. arenaria e M. morocciensis. As cultivares de soja testadas foram as mesmas para os dois ensaios, sendo individualmente inoculadas com 5.000 ovos + juvenis do segundo estádio (J2) de Meloidogyne mantidas em casa de vegetação. Decorridos 60 dias da inoculação, as raízes de cada planta foram avaliadas quanto ao número de galhas, população final e fator de reprodução ( $F R=$ população final/população inicial). A seguir, as médias das diferentes variáveis foram comparadas entre si pelo teste de agrupamento de Scott e Knott a $5 \%$. Todas as cultivares de soja avaliadas comportaram-se como suscetíveis a ambos nematoides, com FR variando 3,5 a 24,1 para $M$. arenaria, e de 5,3 a 37,5 para o M. morocciensis.

PALAVRAS-CHAVE: Glycine max, nematoide-das-galhas, reprodução, suscetibilidade.

\section{INTRODUCTION}

Soybean (Glycine max) is one of the most socioeconomically important crops for the world and Brazil. The world's soybean production is approximately 320 million tons, while Brazil produces about 96 million tons in an area of about 36 million hectares (CONAB 2019). However, this production is affected by the onset of diseases, which may be caused by fungi, bacteria, viruses, and nematodes, capable of drastically decreasing productivity.

In the various soybean-producing regions around the world, over 100 species of plant-parasitic nematodes have been reported for causing infection and crop damage (DIAS et al. 2010). These species are distributed across 50 genera and cause an estimated 30\% in average losses when associated with the soybean crop, making crop production completely unfeasible in extreme cases (DIAS et al. 2010). Nevertheless, losses vary depending on the plant-parasitic nematode species, population levels, 
susceptibility of the cultivar or genotype, and the growing season of the year (ASMUS 2001, BELLÉ et al. 2017).

In Brazil, root-knot nematodes (Meloidogyne spp.) and lesion nematodes (Pratylenchus spp.) are the most common nematodes related to soybean crop damage (DIAS et al. 2010). Symptoms of damage in the soybean crop by plant-parasitic nematodes are generally observed in patches where the plants are stunted and yellowish and in the roots where there are twigs or lesions of varying number and size, depending on the susceptibility of the cultivar or genotype, and the nematode population density in the soil (DIAS et al. 2010). In this context, using genotypes that are resistant to plant-parasitic nematodes is advantageous: they reduce nematode reproduction and the risk of environmental contamination; they are easy to use and do not require special equipment; and their cost of acquisition is similar to the cost of seeds of susceptible cultivars (ARAUJO et al. 2012).

In recent years, the expansion of soybean cultivation areas has evidenced the exposure of the crop to other species of the genus Meloidogyne, such as M. arenaria and M. morocciensis (KIRSCH et al. 2016, MATTOS et al. 2016). The literature has few studies related to these species' reaction to the soybean crop. Given the occurrence of these species in soybean plants, studies on the resistance of soybean materials to root-knot nematodes are important for better crop management planning. Therefore, the aim of this study was to evaluate the reaction of soybean genotypes to $M$. arenaria and $M$. morocciensis under greenhouse conditions.

\section{MATERIAL AND METHODS}

In 2018, two greenhouse trials were conducted to observe the reaction of 28 soybean genotypes (Table 1) to the nematodes $M$. arenaria (January to April) and M. morocciensis (February to June). A completely randomized design with ten replications was adopted for all trials. The initial inocula of $M$. arenaria (Est. A2) and M. morocciensis (Est. A3) were taken from pure populations of their respective species that had multiplied in tomato plants (Solanum lycopersicum) of the Santa Clara cultivar. As proposed by CARNEIRO \& ALMEIDA (2001), the isozyme electrophoresis technique was performed to confirm the species.

Three days after emergence, individual soybean plants of different genotypes were transplanted to pots $\left(2,000 \mathrm{dm}^{3}\right)$ containing sterilized substrate (mixture of sand and soil at a 2:1 ratio). Five days after transplantation, the plants were inoculated separately with different species of Meloidogyne using a suspension of 5,000 eggs + second-stage juveniles (J2) (initial population) based on the method of HUSSEY \& BARKER (1973) and modified by BONETI \& FERRAZ (1981). Santa Clara tomatoes were used for viability testing of the inoculum.

The soil used in the experiment is classified as dystrophic Red Oxisol and has the following physicochemical properties: clay $=61 \%$; water $\mathrm{pH}$ value $=6.2$; SMP index $=6.5$; organic matter $=3.1 \%$; phosphorus $=10.9 \mathrm{mg} \mathrm{dm}^{-3} ;$ potassium $=88 \mathrm{mg} \mathrm{dm}^{-3} ;$ calcium $=5.3 \mathrm{cmol}_{\mathrm{c}} \mathrm{dm}^{-3} ;$ magnesium $=5.0 \mathrm{cmol}_{\mathrm{c}}$ $\mathrm{dm}^{-3}$; and sulfur $=10 \mathrm{cmol}_{\mathrm{c}} \mathrm{dm}^{-3}$.

Sixty days after inoculation, the root system was washed individually under tap water. After removing the excess water with paper towels, it was weighed, and the number of galls were counted. Following the method of HUSSEY \& BARKER (1973), the root systems were processed using a $0.5 \%$ sodium hypochlorite solution to triturate the roots in a blender to obtain the final suspension and quantify the nematode population. Additionally, the number of nematodes per gram of root was estimated, which is determined by the ratio between the total number of nematodes and the total mass of the roots in grams in each replicate.

The experiment was conducted twice, and the similarity between the experiments was tested by a preliminary analysis of variance (ANOVA) using experimental runs as factors in order to determine the interaction between experiment and treatment. This interaction was not significant, thereby allowing data to be combined for ANOVA. Hartley's test (homoscedasticity) was used to analyze data sets (NG, NNGR, and $\mathrm{RF}$ ) prior to the one-way analysis of variance (ANOVA). Subsequently, treatments were compared with the Scott-Knott cluster analysis at a 95\% confidence level using the GENES software. Furthermore, the soybean genotype's reaction was classified according to the reproduction factor (RF) values for each of the nematodes tested $(\mathrm{RF}=$ final population $(\mathrm{Pf})$ /initial population $(\mathrm{Pi}))$, a method proposed by OOSTENBRINK (1966), where rice cultivars were classified as resistant when $R F<1.00$ and susceptible when $R F>1.00$. 
Table 1. Description of commercial soybean genotypes and their respective characteristics.

\begin{tabular}{|c|c|c|c|}
\hline Genotype & Breeder & Growth habit & Maturation Group \\
\hline BMX Alvo RR & Brasmax & Undetermined & 5.9 \\
\hline BMX Apolo RR & Brasmax & Undetermined & 5.5 \\
\hline BMX Garra IPRO & Brasmax & Undetermined & 6.3 \\
\hline BMX Ícone IPRO & Brasmax & Undetermined & 6.8 \\
\hline BMX Lança IPRO & Brasmax & Determined & 5.6 \\
\hline BMX Ponta IPRO & Brasmax & Undetermined & 6.6 \\
\hline BMX Potencia RR & Brasmax & Undetermined & 6.7 \\
\hline BMX Raio IPRO & Brasmax & Undetermined & 5.0 \\
\hline BMX Tornado RR & Brasmax & Undetermined & 6.2 \\
\hline BMX Turbo RR & Brasmax & Undetermined & 5.8 \\
\hline BMX Veloz RR & Brasmax & Undetermined & 5.0 \\
\hline BMX Zeus IPRO & Brasmax & Undetermined & 5.5 \\
\hline BRS 246 RR & Embrapa & Determined & 7.0 \\
\hline BRSMT Pintado & Embrapa & Undetermined & 8.4 \\
\hline CD 235 RR & Coodetec & Semi-determined & 6.4 \\
\hline FPS Atalanta IPRO & Fundação Pró-sementes & Undetermined & 5.7 \\
\hline FPS Urano RR & Fundação Pró-sementes & Determined & 6.3 \\
\hline FPS Solar IPRO & Fundação Pró-sementes & Undetermined & 6.3 \\
\hline Fundacep 58 RR & Fundacep & Determined & 6.8 \\
\hline GMX Redomão RR & Gmax Genética & Undetermined & 6.2 \\
\hline GMX Xiru RR & Gmax Genética & Undetermined & 6.4 \\
\hline HO Amambay IPRO & Ho Genetica & Undetermined & 5.8 \\
\hline HO Arinos RR & Ho Genetica & Undetermined & 7.1 \\
\hline HO Iriri RR & Ho Genetica & Undetermined & 7.1 \\
\hline NA 5909 RR & Nidera & Undetermined & 6.2 \\
\hline NS 5959 RR & Nidera & Undetermined & 6.9 \\
\hline TEC 5936 IPRO & CCGL TEC & Undetermined & 6.1 \\
\hline TMG 7067 INOX & $\begin{array}{c}\text { Tropical Melhoramento e } \\
\text { Genética }\end{array}$ & Semi-determined & 6.7 \\
\hline
\end{tabular}

\section{RESULTS AND DISCUSSION}

Based on the results, all the soybean genotypes in the study were susceptible (RF>1.00) to $M$. arenaria and $M$. morocciensis (Tables 2 and 3). However, different levels of susceptibility were observed between the genotypes. In the tomato plants used to verify the viability of the $M$. arenaria and $M$. morocciensis inocula, the values for RF were 36 and 54, respectively. Therefore, viability of the inocula used in the experiments was confirmed.

The highest incidence of galls caused by $M$. arenaria was observed for soybean genotypes BMX Icone IPRO, BMX Lança IPRO, and BRSMT Pintado, with 556 to 626 galls per plant (Table 2). While the genotypes HO Arinos RR, HO Amambay IPRO, CD 235 RR, HO Iriri RR, BMX Raio IPRO, BMX Zeus IPRO, BMX Turbo RR, Fundacep 58, GMX Redomão RR, NS 5959 RR, BMX Apolo RR, and FPS Atalanta IPRO presented the lowest number of galls caused by $M$. arenaria, differing statistically from the other genotypes (Table 2). As for the number of galls caused by M. morocciensis in each root system, the genotypes with the lowest values were HO Arinos RR and HO Amambay IPRO at 281 and 298 galls, respectively (Table 3). The TEC 5936 IPRO, TMG 7067 INOX, BMX Icone IPRO, and BRS 246 RR genotypes presented the highest incidence of galls from this nematode, with 557 to 689 galls per root system.

The number of eggs and J2 Meloidogyne per gram of soybean root showed varying responses from the genotypes. HO Amambay IPRO, HO Arinos RR, BMX Ray IPRO, HO Iriri RR, CD 235 RR, and BMX 
Zeus IPRO registered the lowest values for $M$. arenaria, while BMX Icone IPRO, BMX Launches IPRO, and TMG 7067 INOX presented the highest values. (Table 2). The genotypes BRS 246 RR, BMX Zeus IPRO, TMG 7067 INOX, and BMX Icone IPRO exhibited the highest population densities of M. morocciensis per gram of root, while HO Amambay IPRO, HO Arinos RR, and BMX Potencia RR had the lowest, thus differing significantly from the other genotypes (Table 3).

Table 2. Number of galls (NG), number of nematodes per gram of root (NNGR), and reproduction factor (RF) of Meloidogyne arenaria in different soybean genotypes.

\begin{tabular}{|c|c|c|c|c|c|c|c|}
\hline Genotypes & $N G$ & & $\mathrm{NNGR}^{1}$ & & $\mathrm{FR}^{2}$ & & Reaction $^{3}$ \\
\hline BMX Alvo RR & 345 & $\mathrm{C}^{4}$ & 2361 & $\mathrm{C}$ & 14,0 & $\mathrm{C}$ & $S$ \\
\hline BMX Apolo RR & 299 & $\mathrm{D}$ & 1811 & $\mathrm{C}$ & 11,5 & $D$ & $S$ \\
\hline BMX Garra IPRO & 344 & C & 2372 & $\mathrm{C}$ & 13,2 & C & $S$ \\
\hline BMX Ícone IPRO & 556 & $A$ & 4021 & $A$ & 21,1 & $A$ & $S$ \\
\hline BMX Lança IPRO & 572 & $A$ & 4198 & $A$ & 22,0 & $A$ & $S$ \\
\hline BMX Ponta IPRO & 432 & $B$ & 2943 & $B$ & 16,6 & $B$ & $S$ \\
\hline BMX Potência RR & 431 & $B$ & 2570 & C & 16,6 & $B$ & $S$ \\
\hline BMX Raio IPRO & 161 & $D$ & 796 & $\mathrm{D}$ & 6,2 & $E$ & $S$ \\
\hline BMX Tornado RR & 445 & $D$ & 2541 & C & 16,4 & C & $S$ \\
\hline BMX Turbo RR & 213 & $D$ & 1796 & C & 8,2 & $D$ & $S$ \\
\hline BMX Veloz RR & 366 & C & 2479 & C & 14,1 & C & $S$ \\
\hline BMX Zeus IPRO & 165 & $D$ & 1105 & $\mathrm{D}$ & 6,4 & $E$ & $S$ \\
\hline BRS 246 RR & 393 & C & 3222 & B & 15,1 & C & $S$ \\
\hline BRSMT Pintado & 626 & $A$ & 3186 & $B$ & 24,1 & $A$ & $S$ \\
\hline CD 235 RR & 147 & $\mathrm{D}$ & 1052 & $\mathrm{D}$ & 5,7 & $E$ & $S$ \\
\hline FPS Atalanta IPRO & 301 & $\mathrm{D}$ & 2280 & $\mathrm{C}$ & 11,6 & $\mathrm{D}$ & $S$ \\
\hline FPS Urano RR & 340 & C & 2174 & $\mathrm{C}$ & 13,1 & C & $S$ \\
\hline FPS Solar IPRO & 385 & C & 2547 & $\mathrm{C}$ & 11,8 & $\mathrm{D}$ & $S$ \\
\hline Fundacep 58 & 272 & $D$ & 2432 & C & 10,5 & $D$ & $S$ \\
\hline GMX Redomão RR & 281 & $D$ & 2057 & C & 10,8 & D & $S$ \\
\hline GMX Xiru RR & 452 & $B$ & 2607 & C & 17,4 & B & $S$ \\
\hline HO Amambay IPRO & 96 & $D$ & 554 & $\mathrm{D}$ & 3,7 & $E$ & $S$ \\
\hline HO Arinos RR & 91 & $D$ & 580 & $\mathrm{D}$ & 3,5 & $E$ & $S$ \\
\hline HO Iriri RR & 156 & $\mathrm{D}$ & 1030 & $\mathrm{D}$ & 6,0 & $E$ & $S$ \\
\hline NA 5909 RR & 359 & C & 2066 & C & 13,8 & C & $S$ \\
\hline NS 5959 RR & 282 & $D$ & 1975 & C & 10,8 & $\mathrm{D}$ & $S$ \\
\hline TEC 5936 IPRO & 379 & C & 2129 & C & 17,4 & B & $S$ \\
\hline TMG 7067 INOX & 420 & $\mathrm{~B}$ & 4210 & $A$ & 23,2 & A & $S$ \\
\hline Tomato (control) & 920 & - & 5515 & - & 36 & - & $S$ \\
\hline CV (\%) & 21,7 & - & 27,78 & - & 24,8 & - & - \\
\hline
\end{tabular}

${ }^{1}$ Number of nematodes per gram of root: ratio between total nematodes and total root mass. ${ }^{2} \mathrm{RF}=$ Final population/Initial population. ${ }^{3}$ Reaction based on OOSTENBRINK (1966): resistant (R) (RF<1.0) and susceptible (S) (RF $\left.\geq 1.0\right) .{ }^{4}$ Means followed by the same letter in each column do not differ significantly by the Scott-Knott test at $5 \%$ probability.

Reproduction of root-knot nematodes in the different soybean genotypes showed the highest reproduction factor values for $M$. arenaria in BMX Icone IPRO, BMX Lance IPRO, TMG 7067 INOX, and BRSMT Pintado presented, ranging from 21.1 to 24.1 (Table 2). The genotypes HO Arinos RR, HO Amambay IPRO, and CD 235 RR had the lowest reproduction factor values at 3.5, 3.7, and 5.7, respectively. The highest reproduction factor values for $M$. morocciensis was observed in the genotypes BMX Icone IPRO and BRS $246 \mathrm{RR}$, at 32.7 and 37.5, respectively (Table 3). However, the genotypes HO Arinos RR and HO Amambay IPRO demonstrated the lowest reproduction factor values, ranging between 5.3 and 5.9, for this 
nematode (Table 2).

Table 3. Number of galls (NG), number of nematodes per gram of root (NNGR), and reproduction factor (FR) of Meloidogyne morocciensis in different soybean genotypes.

\begin{tabular}{|c|c|c|c|c|c|c|c|}
\hline Genotypes & $N G$ & & $\mathrm{NNGR}^{1}$ & & $\mathrm{FR}^{2}$ & & Reaction $^{3}$ \\
\hline BMX Alvo RR & 509 & $\mathrm{C}^{4}$ & 2773 & $\mathrm{D}$ & 16,9 & C & $S$ \\
\hline BMX Apolo RR & 553 & C & 3548 & C & 20,0 & C & $S$ \\
\hline BMX Garra IPRO & 432 & $\mathrm{D}$ & 2459 & $\mathrm{D}$ & 11,9 & $\mathrm{D}$ & $S$ \\
\hline BMX Ícone IPRO & 707 & $A$ & 6122 & $A$ & 32,7 & A & $S$ \\
\hline BMX Lança IPRO & 616 & B & 4251 & B & 24,7 & B & $S$ \\
\hline BMX Ponta IPRO & 618 & $\mathrm{~B}$ & 3923 & B & 24,9 & B & $S$ \\
\hline BMX Potencia RR & 375 & $\mathrm{D}$ & 1156 & $E$ & 9,3 & D & $S$ \\
\hline BMX Raio IPRO & 330 & $\mathrm{D}$ & 1677 & $\mathrm{D}$ & 8,5 & D & $S$ \\
\hline BMX Tornado RR & 426 & $\mathrm{D}$ & 2526 & $\mathrm{D}$ & 11,8 & D & S \\
\hline BMX Turbo RR & 541 & C & 3618 & $\mathrm{~B}$ & 19,8 & C & $S$ \\
\hline BMX Veloz RR & 388 & $\mathrm{D}$ & 1671 & $\mathrm{D}$ & 9,8 & D & $S$ \\
\hline BMX Zeus IPRO & 610 & B & 5234 & $A$ & 24,4 & B & $S$ \\
\hline BRS 246 RR & 757 & $A$ & 5022 & $A$ & 37,5 & A & $S$ \\
\hline BRSMT Pintado & 358 & $\mathrm{D}$ & 1619 & $\mathrm{D}$ & 8,4 & D & $S$ \\
\hline CD 235 RR & 534 & $\mathrm{C}$ & 3648 & B & 18,5 & C & $S$ \\
\hline FPS Atalanta IPRO & 553 & C & 3304 & C & 19,9 & C & $S$ \\
\hline FPS Urano RR & 601 & $\mathrm{~B}$ & 3401 & C & 20,1 & C & $S$ \\
\hline FPS Solar IPRO & 503 & C & 3936 & B & 16,7 & C & $S$ \\
\hline Fundacep 58 & 507 & C & 3223 & C & 16,8 & C & $S$ \\
\hline GMX Redomão RR & 644 & B & 4071 & B & 27,0 & B & $S$ \\
\hline GMX Xiru RR & 540 & C & 4503 & $\mathrm{~B}$ & 26,5 & $B$ & S \\
\hline HO Amambay IPRO & 298 & $E$ & 835 & $E$ & 5,9 & $E$ & $S$ \\
\hline HO Arinos RR & 281 & $E$ & 849 & $E$ & 5,3 & $E$ & S \\
\hline HO Iriri RR & 378 & $\mathrm{D}$ & 1628 & $\mathrm{D}$ & 9,3 & $\mathrm{D}$ & S \\
\hline NA 5909 RR & 581 & C & 3240 & C & 22,2 & C & $S$ \\
\hline NS 5959 RR & 521 & C & 3128 & $\mathrm{C}$ & 17,8 & C & $S$ \\
\hline TEC 5936 IPRO & 689 & $A$ & 4732 & $B$ & 28,4 & $B$ & $S$ \\
\hline TMG 7067 INOX & 690 & $A$ & 5740 & $A$ & 27,8 & B & S \\
\hline Tomato (control) & 902 & - & 8399 & - & 54,0 & - & $S$ \\
\hline CV (\%) & 20,9 & - & 26,8 & - & 25,11 & - & - \\
\hline
\end{tabular}

${ }^{1}$ Number of nematodes per gram of root: ratio between total nematodes and total root mass. ${ }^{2} \mathrm{RF}=$ Final population/lnitial population. ${ }^{3}$ Reaction based on OOSTENBRINK (1966): resistant (R) $(\mathrm{RF}<1.0)$ and susceptible (S) $(\mathrm{RF} \geq 1.0) .{ }^{4}$ Means followed by the same letter in each column do not differ significantly by the Scott-Knott test at $5 \%$ probability.

The results show that all the soybean genotypes in the study are susceptible to $M$. arenaria and $M$. morocciensis. Unfortunately, sources of resistance to these and other species of root-knot nematodes of soybean are scarce. Most of the cultivars considered to be resistant to these nematodes descend from a single source of resistance, the "Bragg" genotype. In addition to the Bragg genotype, there are other sources of resistance that are used to a lesser extent in breeding programs, such as the Hartwig, Kirby, Cordell, and Leflore genotypes, which, in addition to the resistance genes for Meloidogyne, also have resistance genes for H. glycines (SILVA 2001).

The susceptibility of soybean genotypes to $M$. arenaria and M. morocciensis is an important indication of the need for other control measures for this plant parasite, since these species are widespread in cultivated areas. Although several management strategies are applied to increase crop yield, none have been fully effective in keeping populations below the level of economic loss (DIAS-ARIEIRA et al. 2018). Research on genetic resistance is important from the perspective of controlling plant-parasitic nematodes since the responses to these pathogens are reproduced in these hosts. In this sense, multiplication of $M$. arenaria and $M$. morocciensis in soybean generally occurs rapidly and reaches high levels within a short 
period of time.

The most widely used strategy for controlling nematodes in the soil is rotation/succession with nonhost or poor-host crops and the use of resistant soybean genotypes when commercially available (DIASARIEIRA \& CHIAMOLERA 2011, SCHMITT \& BELLÉ 2016). Genetic materials with lower susceptibility can also be used, as observed in this study, and can serve as a tool to contribute to proper management. However, when selecting soybean genotypes, in addition to nematode resistance, their adaptation and yield potential in the region should also be considered.

Other control measures should also be implemented for the integrated management of these nematodes, such as recovering organic matter and soil microbial activity, aiding the population growth of the natural enemies of nematodes, using antagonistic or non-host plants, and applying systemic nematicides (SANTANA-GOMES et al. 2014). The combined use of these management techniques will help decrease the initial nematode population in soybean-producing areas, thereby resulting in fewer problems and higher crop yields.

\section{REFERENCES}

ARAUJO FF et al. 2012. Controle genético, químico e biológico de meloidoginose na cultura da soja. Pesquisa Agropecuária Tropical 42: 220-224.

ASMUS GL. 2001. Danos causados à cultura da soja por nematoides do gênero Meloidogyne. In: SILVA JFV. (Org.). Relações parasito-hospedeiro nas meloidoginoses da soja. Londrina: Embrapa Soja. p.39-62.

BELLÉ C et al. 2017. Reação de cultivares de soja a Pratylenchus brachyurus. Agrarian 10: 136-140.

BONETI JIS \& FERRAZ S. 1981. Modificação do método de Hussey \& Barker para extração de ovos de Meloidogyne exigua em raízes de cafeeiro. Fitopatologia Brasileira 6: 553.

CARNEIRO RMDG \& ALMEIDA MRA. 2001. Técnica de eletroforese usada no estudo de enzimas dos nematoides de galhas para identificação de espécies. Nematologia Brasileira 25: 35-44.

CONAB. 2019. Companhia Nacional de Abastecimento. Safras: séries históricas. Brasília: CONAB. Disponível em: http://www.conab.gov.br/safras.asp. Acesso em: 18 Jan. 2019.

DIAS WP et al. 2010. Nematoides em soja: identificação e controle. Londrina: Embrapa Soja. 8p. (Circular Técnica 76).

DIAS-ARIEIRA CR \& CHIAMOLERA FM. 2011. Cresce a incidência de nematoides em milho e soja. Revista Campo e Negócios 97: 18-21.

DIAS-ARIEIRA CR et al. 2018. Biological control of in soya bean crops. Journal of Phytopathology 166: 722-728.

HUSSEY RS \& BARKER KR. 1973. A comparison of methods of collecting inocula of Meloidogyne spp., including a new technique. Plant Disease Reporter 57: 1025-1028.

KIRSCH VG et al. 2016. Caracterização de espécies de Meloidogyne e de Helicotylenchus associadas à soja no Rio Grande do Sul. Nematropica 46: 197-208.

MATTOS VS et al. 2016. Meloidogyne spp. populations from native Cerrado and soybean cultivated areas: genetic variability and aggressiveness. Nematology 18: 505-515.

OOSTENBRINK R. 1966. Major characteristics of the relation between nematodes and plants. Mededeelingen der Landbouw-Hoogeschool 66: 1-46.

SANTANA-GOMES SM et al. 2014. Crop succession in the control of Pratylenchus brachyurus in soybean. Nematropica 44: $200-206$.

SCHMITT J \& BELLÉ C. 2016. Reação de cultivares de soja a Meloidogyne javanica e M. incognita. Nematropica 46: 76-80.

SILVA JFV. 2001. Resistência Genética de soja a nematoides do gênero Meloidogyne. In: SILVA JFV. (Org.). Relações parasito-hospedeiro nas meloidoginoses da soja. Londrina: Embrapa Soja. p.95-127. 